\title{
Laser Texturing as Substrate Preparation Technique for Improved Corrosion Performance on WC-Co HVOF Coatings on AZ91D
}

\author{
Sachpreet Singh Aulakh ${ }^{1}$, Gagandeep Kaushal ${ }^{2}$ and Neeraj Bala ${ }^{3}$ \\ ${ }^{1}$ Research Scholar, Department of Mechanical Engineering, Punjab Technical University, Punjab, India \\ ${ }^{2}$ Assistant Professor, Yadavindra College of Engineering, \\ Punjabi University Guru Kashi Campus, Talwandi Sabo, Bathinda, Punjab, India \\ ${ }^{3}$ Associate Professor, Mechanical Engineering Department, BBSBEC, Fatehgarh Sahib, Punjab, India \\ E-Mail: sachaulakh@gmail.com
}

\begin{abstract}
Substrate preparation plays a vital role in the performance of thermal spray coatings. Adherence of the coating to the substrate depends on surface characteristics like; mechanical interlocking, physio-chemical properties of surface and metallurgical bonding. The surface characteristics depend to great extent on the method used for substrate preparation. In the present study, WC-12Co and WC-17Co coatings were deposited on AZ91D samples prepared using laser texturing as substrate preparation technique. Laser textured substrate was characterized using scanning electron microscopy and surface roughness tester. Bond strength of the coating was determined using ASTM 633C pull off test. SEM was used to study the morphology of the coating; XRD/EDAX techniques were used to study the structure of the coatings. Porosity and micro-hardness of the coatings were also measured. Corrosion performance of the coatings was determined using Potentiodynamic and EIS electrochemical corrosion testing techniques. The coatings are found to have good surface and mechanical properties. Both WC-12Co and WC-17Co demonstrated good corrosion performance during electrochemical testing. However, WC-12Co was found to better protect the AZ91D compared to WC-17Co.

Keywords: AZ91D, Corrosion, HVOF, Laser Texturing, Substrate Preparation
\end{abstract}

\section{INTRODUCTION}

In this era of global warming and legislations for tighter emission controls, magnesium alloys can be the material of choice for automobile and aerospace industry. Magnesium alloys possess high specific strength along with good formability, making it very promising for applications where low weight materials are required. However, use of magnesium alloys is limited on account of its low wear and corrosion resistance $[1,2]$. A suitable surface treatment can economically protect the surface of alloy against wear and corrosion. Thermal spraying technology is widely used in automotive industry to produce coatings on transmission and engine parts such as synchronizing rings, shift forks and large volume of piston rings [3]. To increase the corrosion resistance and mechanical properties of the surfaces in question, cermet materials have been largely used for applications on aluminum alloys [4-6]. Largely, $\mathrm{Al} / \mathrm{Si}-\mathrm{C}$ and $\mathrm{Al} / \mathrm{A} 12 \mathrm{O} 3$ thermal spray coatings have been used against corrosion and wear in case of magnesium alloys however all of these coatings need some sort of post coating treatment to reduce porosity $[1,2,7,8]$.
WC-Co coatings have been widely used for excellent wear and corrosion performance on variety of substrates but its performance is yet to be studied for AZ91D magnesium alloys. Maria Parco et al, [9] investigated the corrosion performance of HVOF sprayed WC-12Co coating on AZ91 and AE42 magnesium alloys using salt spray corrosion test. They concluded that WC-12Co coating realized on $\mathrm{Al}$ bond coat provided better corrosion performance as compared to coating without bond coat. However bond coat adds to the cost and production complexity. The corrosion studies on the use of WC-Co coatings on AZ91D are scarce and warrant for further investigation using standard electrochemical corrosion testing methods to understand the corrosion phenomenon in such coatings.

In order to create good conditions to anchor coatings on the substrate, appropriate surface preparation is required [10]. Specific chemical, physical and mechanical characteristics are required on the substrate surface for good coating adhesion [11]. Conventional substrate preparation techniques consist of degreasing the surface with some solvents and subsequent grit blasting. But in the case of ductile materials like aluminum \& magnesium alloys, grit blasting damages the surface in addition to some grits getting embedded into the surface apart from the risk of micro-cracks on the surface [12]. An alternative substrate preparation method with better coating adhesion and surface properties can improve the life of the coatings. Laser texturing is one such substrate preparation technique which has already been successfully used for aluminum alloys [13]. Aluminum and magnesium alloys possess similar mechanical and surface properties. It will be interesting to see the effectiveness of laser texturing in realization of high performance HVOF WC-Co coating on AZ91D magnesium alloy. In the present study, surface properties and electrochemical corrosion performance of the HVOF sprayed WC-Co coating deposited on laser textured AZ91D magnesium alloy have been investigated.

\section{EXPERIMENTAL PROCEDURE}

\section{A. Sample Preparation}

The substrate material used in this study was commercial magnesium alloy AZ91D (Al 8.4\%, Zn 3.2\%, Mn 0.04\%, 
$\mathrm{Cu} 0.03 \%$, Fe $0.02 \%$ ). AZ91D alloy has been selected for the study because magnesium alloys have the potential to be used in automobile parts, aircraft and aerospace industry due to its high specific strength but at the same time, there are limitations over the use of magnesium alloys because of low wear and corrosion resistance. For adhesion strength test, substrate was machined into cylindrical shape $\Phi 25.4$ $\mathrm{mm}$ and length $38.1 \mathrm{~mm}$ as per ASTM633C standard. The samples of dimensions $10 \mathrm{~mm} \times 10 \mathrm{~mm} \times 8 \mathrm{~mm}$ were prepared for electrochemical corrosion testing.

As machined AZ91D samples have been laser textured on Nd:YAG Q switch laser system. The laser characteristics used were, pulse repetition rate $-2 \mathrm{KHz}$, pulse wave duration - $100 \mathrm{~ns}$ and average power $-20 \mathrm{~W}$. A pattern consisting of matrix of holes, with hole-to-hole distance of $100 \mu \mathrm{m}$ was used to create texture. Scanner stops the laser beam at the points given in the Autocad drawing and multiple pulses are generated for given duration to create the holes. Helium gas has been used as shroud gas to protect the surface from excessive oxidation. Commercial agglomerated and sintered WC-12Co \& WC-17Co Sulzer metco powders with particle size $-45+15 \mu \mathrm{m}$ were used for coating. WC-Co powders have been chosen because of its good wear and corrosion resistance properties. HVOF thermal spray coating technique was used because in HVOF technique particles strike the laser textured holes at high velocity as well as in plasticized state due to high temperature of spray particles. It is assumed that it will lead to good mechanical anchoring as well as some chemical bonding between particles and substrate. HVOF spray parameters used were as given in the table I.

TABLE I HVOF SPRAY PARAMETERS
\begin{tabular}{|l|l|}
\hline Gun & HIPOJET 2700 \\
\hline Spray distance & $180 \mathrm{~mm}$ \\
\hline Oxygen Flow rate & 260 L.min-1 \\
\hline LPG flow rate & 60 L.min-1 \\
\hline Carrier gas- N2 flow rate & 9.4 L.min-1 \\
\hline Air flow rate & 550 L.min-1 \\
\hline Powder feed rate & 38 g/min \\
\hline
\end{tabular}

\section{B. Characterization}

JSM-6510LV scanning electron microscope was used to study the morphology and microstructure of laser textured and grit blasted surfaces and coatings. Energy-dispersive Xray spectroscopy (EDX) technique was used to study the composition of coating and coating-interface. The phase constitutions of powder and coatings were determined using X-ray diffractometer (XRD) operated at $40 \mathrm{~mA}, 45 \mathrm{kV}$. Porosity of the coating was measured at 12 different points using image analysis software, on optical images of coating cross-section and average value has been reported. Coating adhesion strength was investigated using ASTM C633 thermal spray coating adhesion test. An average of three tests was taken to find out adhesion strength. Coating micro hardness was measured on polished cross-section of coating using $200 \mathrm{~g}$ load and $10 \mathrm{~s}$ dwell time using Vickers indentor on Zwick Roell ZHU micro hardness tester. The reported coating values are average of 16 measurements. Coating fracture toughness was measured using indentation method using the following equation [14]; load of $10 \mathrm{Kg}$ and dwell time of $15 \mathrm{~s}$ was used.

$$
079\left(\frac{-3}{-3}\right) \quad g\left(\begin{array}{ll}
4 & -
\end{array}\right)
$$

Where $\mathrm{P}(\mathrm{N})$ represents the load applied to the indenter, a $(\mu \mathrm{m})$ and $\mathrm{c}(\mu \mathrm{m})$ corresponds to half diagonal and crack length of the indentation respectively. To see the effect of substrate preparation technique on hardness of substrate, micro hardness of substrate was measured on the polished cross-section perpendicular to the substrate coating interface. Surface roughness values of the coated samples were measured using a Surfcom 130 2D profilometer (Zeiss) at a cut-off value of $0.8 \mathrm{~mm}$ (average of 6 readings per sample, with $6 \mathrm{~mm}$ evaluation length per reading). The corrosion behaviour of the coating was examined using electrochemical corrosion testing technique. Potentiodynamic polarisation technique and electrochemical impedence spectroscopy (EIS) was used to determine corrosion performance of the coatings compared to AZ91D alloy. The tests were performed on a Gamry's electrochemical workstation using a three electrode cell consisting of saturated calomel electrode (SCE) as a reference electrode, graphite as a counter electrode and WCCo coating specimen as a working electrode in a $3.5 \%$ $\mathrm{NaCl}$ solution. All the specimen were cold mounted using non conduting epoxy with $1 \mathrm{~cm} 2$ area exposed to $3.5 \%$ $\mathrm{NaCl}$ aqueous solution. All the specimen were grinded and polished upto $\mathrm{Ra} 0.5 \mu \mathrm{m}$ and washed in ultrasonic bath containing acetone. Specimen were immersed in $\mathrm{NaCl}$ aqueous solution up to 24 hours prior to commencement of electrochemical testing. After the stabilisation of OCP, potentiodynamic polarisation tests were conducted with scan rate of $0.5 \mathrm{mV} / \mathrm{s}$ and $+250 \mathrm{mV}$ with reference to OCP. EIS tests were conducted at OCP by applying $10 \mathrm{mV}$ sinusoidal potential excitation of $10 \mathrm{mV}$ amplitude over frequency range from $100 \mathrm{kHz}$ to $10 \mathrm{mHz}$. Eachtest was conducted twice to ensure repeatability of experiments.

\section{RESULTS AND DISCUSSION}

\section{A. Substrate Laser Texture Characterization}

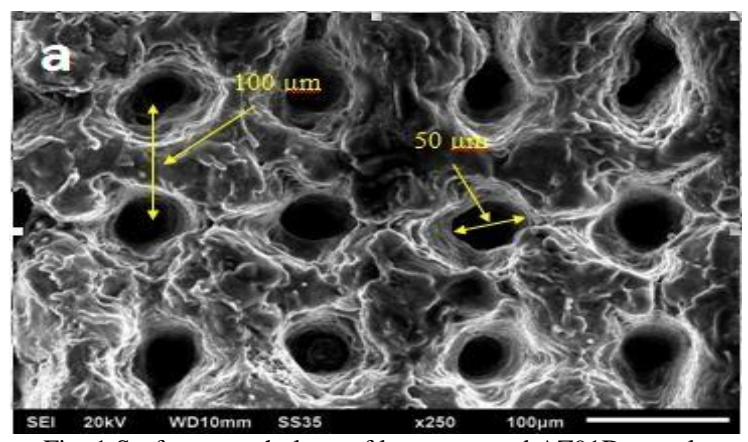

Fig. 1 Surface morphology of laser textured AZ91D sample 


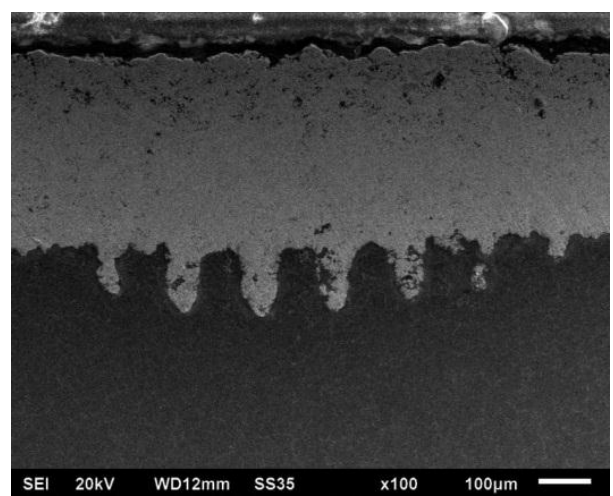

Fig. 2 Coated sample cross-section showing substrate and coating interface

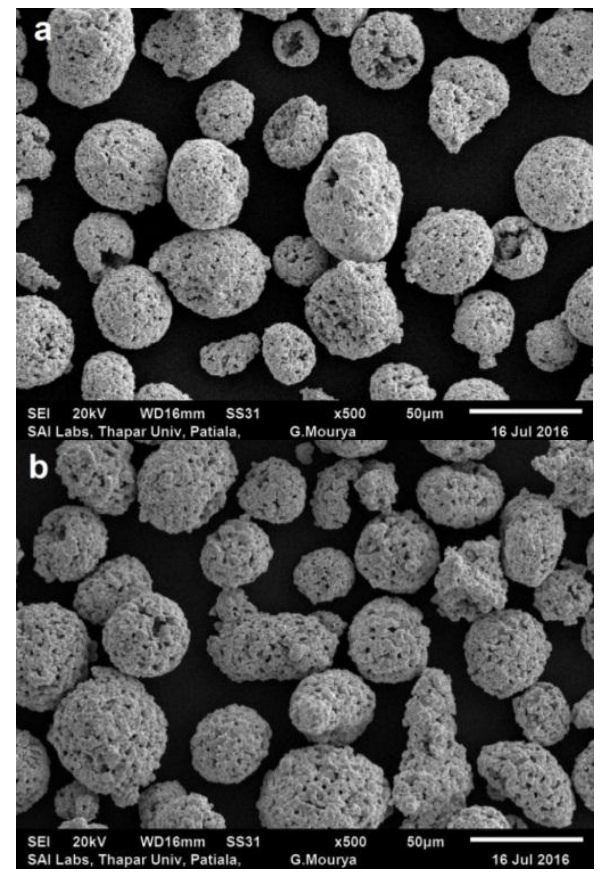

Fig. 3 SEM micrographs of feedstock powder (a) WC-12Co powder (b) WC-17Co powder
In reference to the limitations of grit blasting for aluminum and magnesium alloys as discussed in the introduction part of this paper, laser texturing has been used to prepare the surface for subsequent HVOF coating. SEM micrograph (fig. 1) shows the morphology of laser textured top surface of the samples. Laser generated matrix of micro-holes can be clearly seen on the surface. The micro-holes act as anchors for the coating splats and enhance the adhesion strength of the coating. Figure 2 shows the SEM micrograph of the cross-section of coated sample. Coating can be seen well anchored inside the micro-holes. Average diameter of the micro-holes is found to be $50 \mu \mathrm{m}$ and depth of the holes is around $100 \mu \mathrm{m}$ and hole to hole distance is $100 \mu \mathrm{m}$.

\section{B. Coating Characterization}

SEM images (fig. 3a \& 3b) of the morphology of WC-12Co and WC-17Co feedstock powder show the characteristics porosity of agglomerated and sintered powder. Porosity in the particles promotes uniform heating distribution inside the particle during spray process and it results in homogeneous coating microstructure [4]. The powder size is in the range of $15 \mu \mathrm{m}$ to $45 \mu \mathrm{m}$. Particles are spheroidal in shape and have uniform size distribution.

Uniform distribution of particles promotes flowability during spraying process. Physical characteristics of both the powders are same. Figure 4a shows representative XRD pattern of both the powders. Both the powder do not show any phases like, W2C, other than $\mathrm{WC}$ and Co. The counts of $\mathrm{WC}$ are relatively more in $\mathrm{WC}-12 \mathrm{Co}$ than $\mathrm{WC}-17 \mathrm{Co}$ powder whereas counts of $\mathrm{Co}$ are more in WC-17Co powder. This is in accordance with the composition of powder.

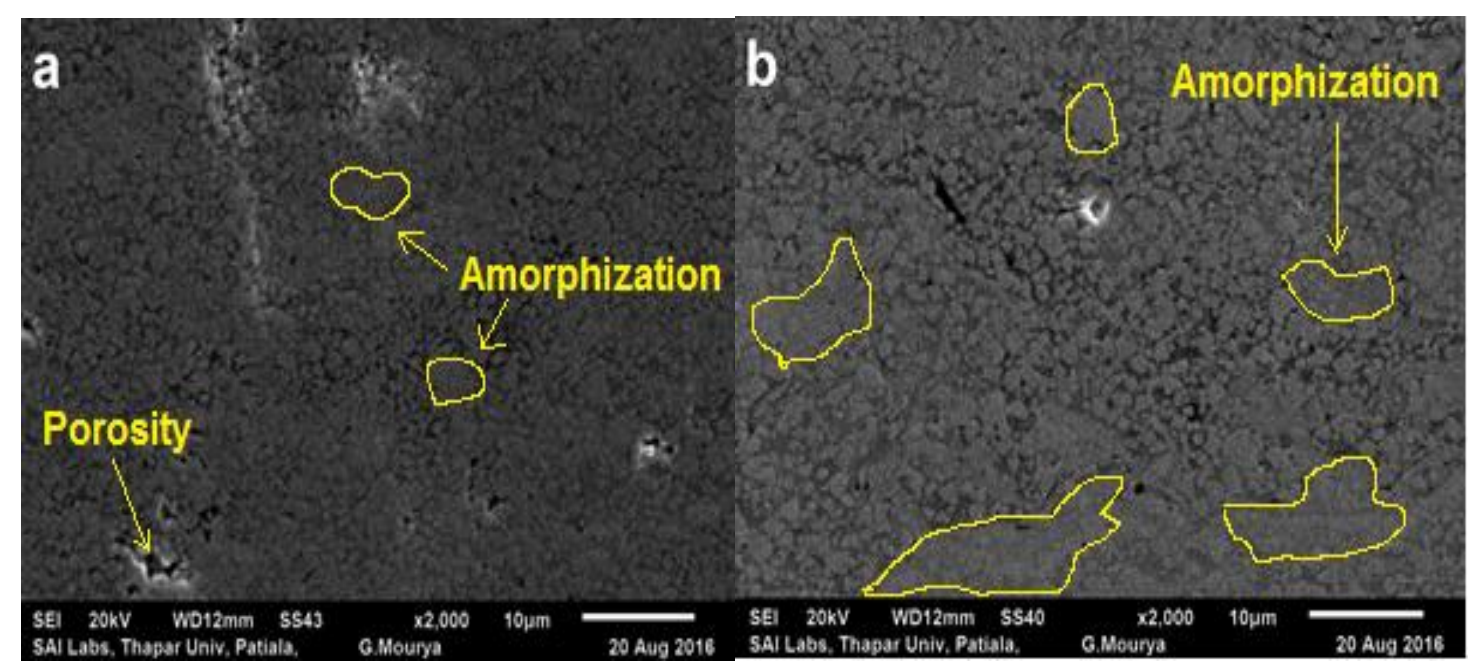

Fig. 4 SEM micrographs of coating cross-section showing coating morphology of (a) WC-17Co coating (b) WC-12Co coating. 


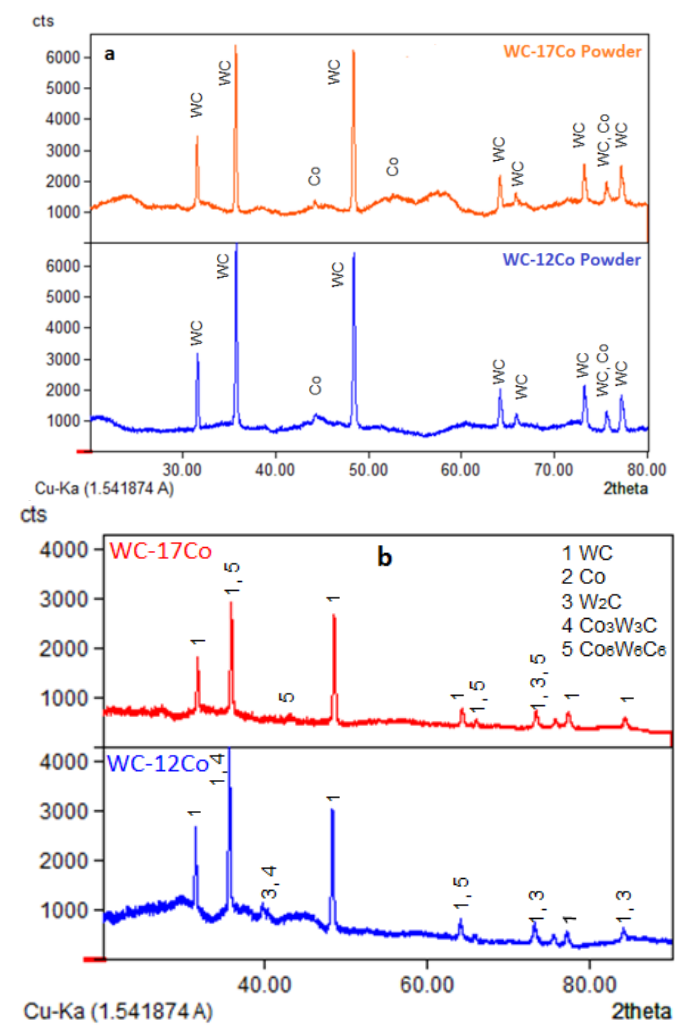

Fig. 5 XRD patterns of the (a) Feedstock powders (b) as sprayed coatings

Figure 2 shows the representative SEM micrograph of the cross-section of WC-12Co coating on laser textured AZ91D alloy. The coating seems to be well bonded at the interface with uniform thickness of $370 \mu \mathrm{m}$ and without any cracks or delamination. Porosity appears to be more at the top of the coating and it reduces towards the interface. Figure 4 shows the SEM micrographs of the cross-section of WC-12Co and WC-17Co coatings at $2000 x$ magnification. In both the coatings WC particles (light grey) are dispersed in dark Cobalt matrix. Compared to WC-17Co coating, WC-12Co coating has (marked out regions in fig. 4b) relatively more melted matrix areas depicting fragile amorphous $\eta$ phases which form due to decarburization and dissolution of WC into Co matrix. This observation can be further corroborated from the XRD patterns of both the coatings. The hump in the XRD pattern between 2theta 200 and 450 indicates the amorphicity or nanostructure in binder phase $[15,16]$. Both the coatings contain $\mathrm{Co} 3 \mathrm{~W} 3 \mathrm{C}, \mathrm{Co} 6 \mathrm{~W} 6 \mathrm{C} \eta$ phases. As can be seen from XRD pattern, amorphization and decomposition of $\mathrm{WC}$ into $\mathrm{W} 2 \mathrm{C}$ is more pronounced in WC-12Co coating than WC-17Co coating. It can also be confirmed by more rounded $\mathrm{WC}$ particles in $\mathrm{WC}-12 \mathrm{Co}$ coating compared to WC-17Co coating as can be seen from fig. $4 \mathrm{a} \& 4 \mathrm{~b}$. In WC-Co coatings, decomposition of the coating increases as cobalt content decreases [17]. Al Hamaali et al attribute this phenomenon to lower in flight temperature of particles in case of higher Co percentage due to higher specific heat capacity and latent heat of $\mathrm{Co}$ as compared to WC.

Porosity can be very detrimental to the effectiveness of coating against corrosion. Electrolyte can reach the substrate coating interface through the interconnected pores and can cause galvanic corrosion at the interface. The resulting buildup of corrosion products can potentially delaminate the coating. Porosity values in the coatings as measured using image analysis of optical images are $0.90 \pm 0.2$ and $0.75 \pm 0.14$ respectively for $\mathrm{WC}-12 \mathrm{Co}$ and WC-17Co coatings. WC-17Co has relatively higher percentage of binder $\mathrm{Co}$ content. Co binder attains plastic phase due to high temperature and WC particles get embedded into plastic Co binder. But in case of WC-12Co incoming WC particles may not embed properly on the already deposited coating particles due to less percentage of Co binder content and bounce off leaving behind a pore. Also, it can be seen from fig. 2, porosity is more in the top layers of the coating than the bottom layers. During HVOF spraying, high velocity coating particles compress the already deposited layers and reduce the porosity in the bottom layers. Micro-hardness of the WC-12Co and WC17Co coatings was found to be $1063.1+121.4 \mathrm{HV} 0.2$ and $996.9 \pm 184.9$ HV0.2 respectively. WC-12Co coating has higher hardness on account of higher percentage of WC in the coating.

Coating adhesion on the substrate is fundamental to promote a good cohesion of the materials and a successful application [18]. ASTM C633 adhesion strength test was conducted on the WC-12Co coated test samples to check adhesion strength of coating on laser textured AZ91D sample. Coating adhesion strength was found to be 45.6 $\mathrm{MPa}$ and mode of failure was glue failure on the uncoated sample glued to coated sample. The results from adhesion strength test on magnesium alloys are limited by the adhesion strength of the glues on magnesium alloys which is $50 \%$ of that achieved on steels [19]. Hence, it can be safely assumed that actual adhesion strength of the coating is much higher than 45.6 MPa.

\section{Electrochemical Corrosion Behaviour}

The potentiodynamic polarization curves for samples L12 (WC-12Co), L17 (WC-17Co) and AZ91D after 12 hour immersion in $3.5 \%$ wt $\mathrm{NaCl}$ are shown in the fig. 6a. The corrosion potential (Ecorr) of samples L17, L12 and AZ91D are $-0.366 \mathrm{~V},-0.377 \mathrm{~V}$ and $-1.428 \mathrm{~V}$ respectively. There is not much difference in the corrosion potential of L17 and L12 coating but corrosion potential of both the coatings is much nobler than the corrosion potential of AZ91D. Corrosion potential of coating depends on the number of factors like, inherent corrosion potential of constituent phases and their relative percentage in the coating, micro galvanic corrosion phenomenon between $\mathrm{WC}$ and $\mathrm{Co}$ and porosity of the coating. The reason behind similar corrosion potential for both coatings can be attributed to similar chemical composition of the coatings. Fig. $6 \mathrm{~b}$ shows the corrosion potential (Ecorr) of both the coatings after 24 hour immersion. It can be seen that there is not much change in the corrosion potential $(-0.378 \mathrm{~V})$ of L12 coating compared to its corrosion potential after 12 hour immersion. However, the corrosion potential of L17 
coating shifts to $-0.550 \mathrm{~V}$ after 24 hours immersion. The corrosion current density of L12 coating is $5.851 \mu \mathrm{A} / \mathrm{cm}^{2}$ which is significantly smaller than $28.23 \mu \mathrm{A} / \mathrm{cm}^{2}$ for L17 coating. Therefore, L12 coating seems to have higher corrosion resistance than L17 coating. After 20 hours immersion in $3.5 \% \mathrm{NaCl}$ solution, M. Couto et al [20] reported similar corrosion potentials for $\mathrm{HVOF} \mathrm{WC}-12 \mathrm{Co}$ and WC-17Co coatings deposited on Al7077-T6 alloy. Higher corrosion resistance for L12 coating can be attributed to higher amorphization and lower metallic cobalt phase of the L12 coating. Over the longer period of immersion, electrolyte can reach the substrate through interconnected pores and can create galvanic cells between
AZ91D substrate and WC-Co coating. Non uniformity in microstructure of WC-Co coating can also lead to formation of micro-galvanic cells between $\mathrm{WC}$ and metallic Co phases. However, amorphized constituents of the coating provide for more uniform and smooth microstructure free of micro-pores and hence higher resistance to corrosion [21]. As has been discussed earlier, L12 coating contains relatively more amorphous phases than L17 coating. Hence, higher amorphization and lower metallic cobalt content of the L12 coating can be said to be the reasons behind its higher corrosion resistance compared to L17 after 24 hours immersion.
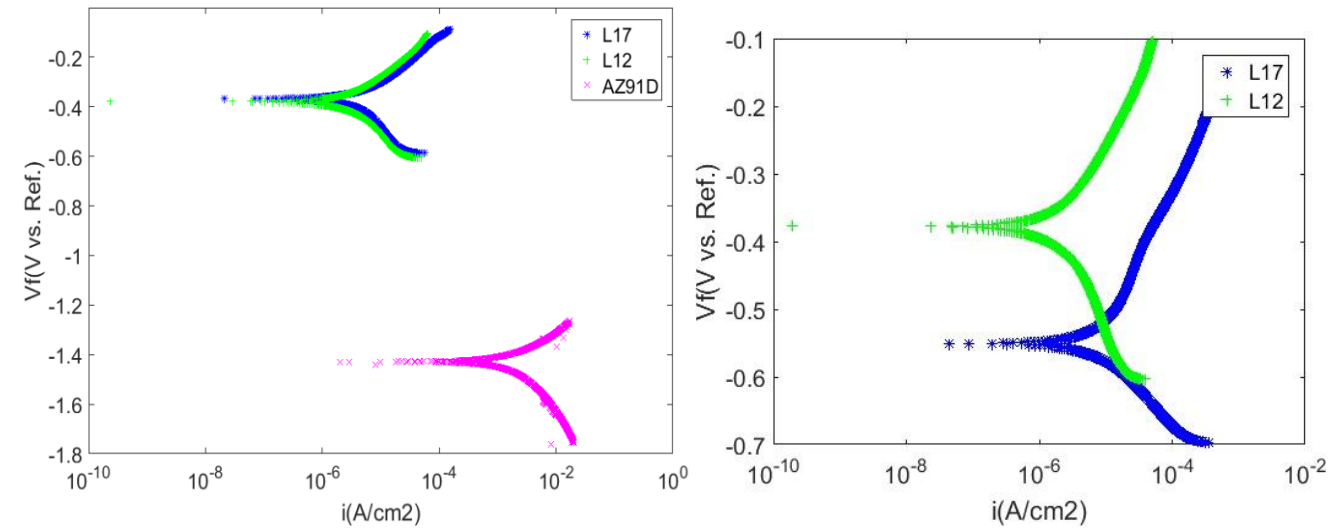

Fig. 6 Potentiodynamic polarization curves for samples L12, L17 and AZ91D in unaerated 3.5\% wt NaCl solution after (a) 12 Hour immersion (b) 24 Hour immersion
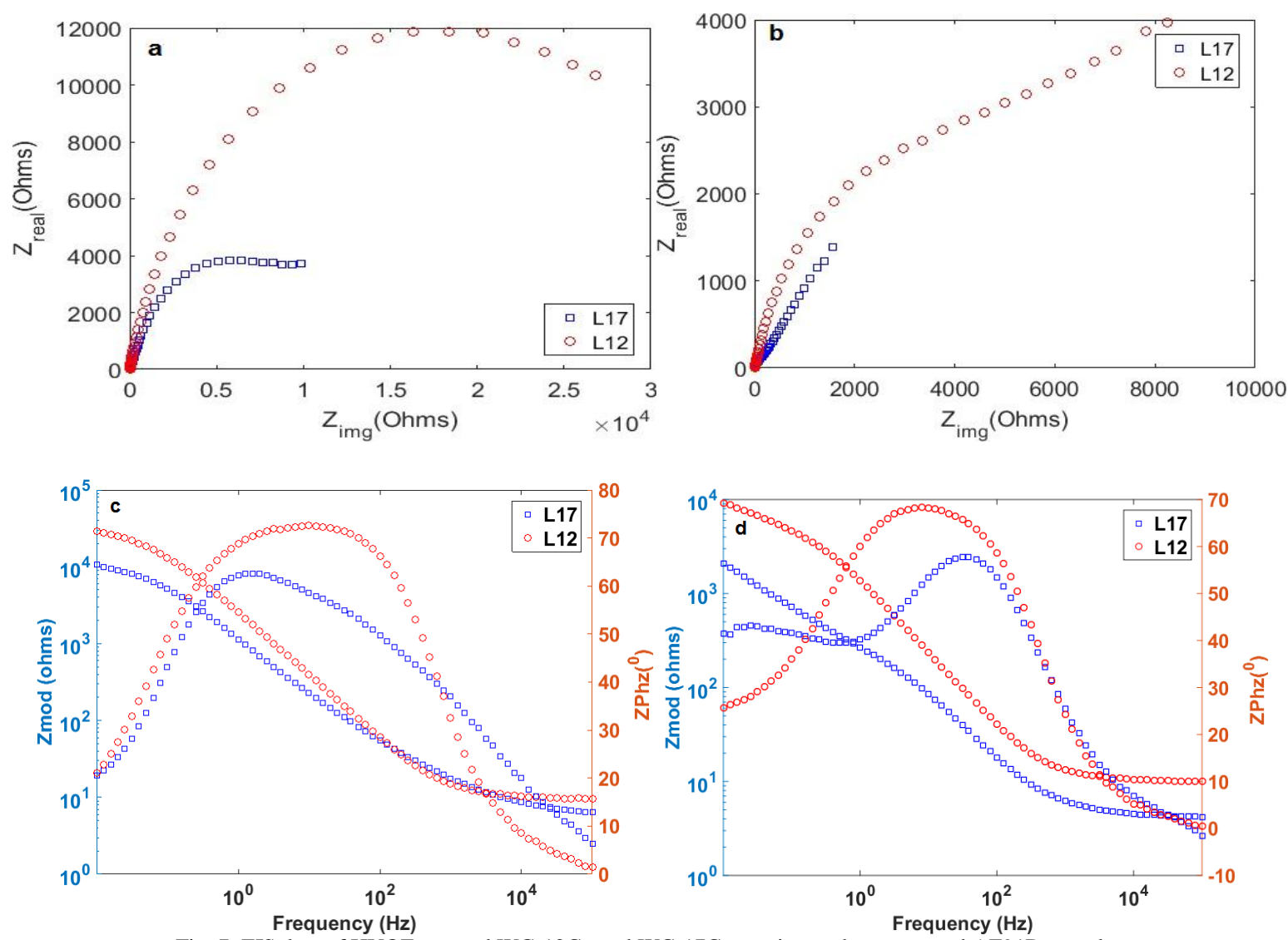

Fig. 7. EIS data of HVOF sprayed WC-12Co and WC-17Co coating on laser textured AZ91D samples 
In $3.5 \%$ wt. $\mathrm{NaCl}$ (a) Nyquist diagrams after 12 hours immersion (b) Nyquist diagrams after 24 hours immersion (c) Bode plot after 12 hours immersion (d) Bode plot after 24 hours immersion. The EIS Nyquist and bode plots conducted on both the coatings at open circuit potential are as shown in fig. 7. Nyquist plots show larger capacitive semi circles for L12 coating as compared to L17 coating. The diameter of the capacitive semi-circle is related to charge transfer resistance which is an indication of corrosion resistance of the coating [22]. These results indicate higher charge transfer resistance and hence higher corrosion resistance for L12 coating. Further, for both coatings capacitive semi-circles are smaller for the tests conducted after 24 hour immersion than that after 12 hours immersion time. It indicates that both coatings have higher resistance to corrosion after 12 hours immersion however after 24 hours immersion corrosion rate increased. It can be because, over the passage of time, more and more electrolyte enters the pores inside the coating and setup micro-galvanic cells between WC and metallic Co, thereby increasing rate of corrosion. It is also interesting to note from Nyquist plot (Fig. 7a) that L12 coating has only one time constant whereas L17 coating has two time constants. The second time constant can be assigned to oxidation of substrate. It means that for L12 coating after 12 hour immersion electrolyte did not reach the substrate yet and hence no corrosion of substrate started as yet however for L17 sample second time constant indicates towards corrosion of AZ91D substrate. In the Nyquist spectrum obtained after 24 hour immersion, even in the case of L12 coating, two time constants can be observed. It means although coating has been successful in protecting the substrate from corrosion attack up to 12 hours, however it may not be able to protect the substrate for longer periods up to 24 hours.

From the bode plots in fig. 7c it can be seen that L12 coating has phase angle around 720 whereas L17 coating's phase angle is around 620. A phase angle less than 900 suggest that the impedance spectrum doesn't confirm to ideal capacitive behavior and hence an ideal coating. However, higher phase angle suggest better protection of the coating against corrosion [4]. Therefore, higher phase angle (720) for L12 coating indicates better corrosion resistance of the coating as compared to L17 coating. EIS spectrum recorded on the cermet based coatings is strongly influenced by coating morphology, that is WC/Co ratio and porosity and dissolution of the substrate strictly depends on the presence of 'through coating pores' [23].

Better corrosion performance of L12 coating as compared to L17 coating can be explained due to higher oxidation dissolution regions of carbides leading to amorphization, and hence higher resistance to corrosion. Further Co has more negative corrosion potential as compared to WC. Overall corrosion potential of the coating depends on the $\mathrm{WC} / \mathrm{Co}$ ratio and coating morphology. Hence, higher Co percentage and less amorphization of the coating in L17 results in lesser corrosion resistance than L12 coating. Both the coatings have some amount of porosity. Over the period of time, electrolyte reaches the substrate and it leads to corrosion of the substrate too. Hence, for successful application, some post-processing treatment like laser ablation will be helpful in closing the pores at the surface of coating and may lead to higher anti-corrosion performance of the coating.

\section{CONCLUSION}

In the present study, surface properties and electrochemical corrosion performance of the HVOF sprayed WC-Co coating deposited on laser textured AZ91D magnesium alloy have been investigated.WC-12Co and WC-17Co coatings were realized on AZ91D samples and the samples were subjected to electrochemical corrosion testing to see the effect of WC/Co ratio on corrosion performance. The main findings of this study are as follows;

1. Both the coatings have lower corrosion potential as compared to AZ91D alloy. However, compared to WC$17 \mathrm{Co}$ coating, WC-12Co coating has better corrosion performance in poteniodynamic and EIS tests.

2. WC-12Co coating has been successfully applied on laser textured AZ91D substrate with coating adhesion strength of $45.6 \mathrm{MPa}$.

3. Decomposition and generation of amorphous phases is more pronounced in $\mathrm{WC}-12 \mathrm{Co}$ coating as compared to $\mathrm{WC}-17 \mathrm{Co}$ coating. However, porosity of $\mathrm{WC}-12 \mathrm{Co}$ coating is relatively more as compared to $\mathrm{WC}-17 \mathrm{Co}$ coating.Both these factors affect the corrosion performance of the coating.

\section{REFERENCES}

[1] Yongshan Tao, Tianyingxiong, Chao Sun, Lingyan Kong et al, "Microstructure and corrosion performance of a cold sprayed aluminium coating on AZ91D magnesium alloy", Corrosion Science, Vol. 52, pp. 3191-3197, 2010.

[2] R Arrabal, A. Pardo, M.C. Merino, M. Mohedano, P. Casajus, S. Merino, "Al/SiC thermal spray coatings for corrosion protection of $\mathrm{Mg}-\mathrm{Al}$ alloys in humid and saline environments", Surface \& Coatings Technology, Vol. 204, pp. 2767-2774, 2010.

[3] A Pardo, P. Casajus, M. Mohedano, A.E. Coy, F. Viejo, B. Torres, E. Matykina, "Corrosion protection of $\mathrm{Mg} / \mathrm{Al}$ alloys by thermal sprayed aluminium coatings", Applied Surface Science, Vol. 255, pp. 69686977, 2009.

[4] M. Magnani, P.H. Suegama, N. Espallargas, S. Dosta, C.S. Fugivara, J.M. Guilemany, A.V. Benedetti, "Influence of HVOF parameters on the corrosion and wear resistance of WC-Co coatings sprayed on AA7050 T7”, Surface \& Coatings Technology, Vol. 202, pp. 4746475, 2008.

[5] HarunMindivan, "Wear behavior of plasma and HVOF sprayed WC$12 \mathrm{Co}+6 \%$ ETFE coatings on AA2024-T6 aluminum alloy", Surface \& Coatings Technology, Vol. 204, pp. 1870-1874, 2010.

[6] M. Barletta, G. gBolelli, B. Bonferroni, and L. Lusvarghi, "Wear and Corrosion Behavior of HVOF-Sprayed WC-CoCr Coatings on $\mathrm{Al}$ Alloys", Journal of Thermal Spray Technology, Vol.19, No. 1-2 January 2010.

[7] M. Campo, M. Carboneras, M.D. Lopez, B. Torres, P.Rodrigo, E. Otero, J. Rams, "Corrosion resistance of thermally sprayed Al and $\mathrm{Al} / \mathrm{SiC}$ coatings on Mg", Surface \& Coatings Technology, Vol. 203, pp. 3224-3230, 2009.

[8] A. Pardo, M.C.Merino, M. Mohedano, P.Casajus, A.E.Coy, R.Arrabal, "Corrosion behavior of $\mathrm{Mg} / \mathrm{Al}$ alloys with composite coatings", Surface \& Coatings Technology, Vol. 203, pp. 1252-1263, 2009. 
[9] Maria Parco, Lidong Zhao, JochenZwick, Kirsten Bobzin, Erich Lugscheider, "Investigation of HVOF spraying on magnesium alloys", Surface \& Coatings Technology, Vol. 201 pp. 3269, 2006.

[10] R.S.C. Paredes, S.C. Amico, A.S.C.M. d'Oliveira: "The effect of roughness and pre-heating of the substrate on the morphology of aluminium coatings deposited by thermal spraying", Surface \& Coatings Technology, Vol. 200, pp. 3049 - 3055, 2006.

[11] G. Spur, E. Uhlmann, F. Elbing: "Dry-ice blasting for cleaning: process, optimization and application", Wear, pp. 233-235_1999, pp. 402-411.

[12] B.J. Griffiths, D.T. Gawne, and D. Dong: "The Role of Grit Blasting in the Production of High Adhesion Plasma Sprayed Alumina Coatings", Proc. Inst. Mech. Eng., Vol. 211, No. 1, part B, pp. 1-9, 1997.

[13] S. S. Aulakh, G. Kaushal, "Substrate preparation \& thermal spray coating performance - a review", International Thermal Spray Conference \& Exposition ITSC, Vol. 324, 28, 2016

[14] A. Lekatou, D. Sioulas, A.E. Karantzalis, D, Grimanelis, "A comparative study on the microstructure and surface property evaluation of coatings produced from nanostructured and conventional WC-Co powders HVOF sprayed on A17075", Surface and Coatings Technology, Vol. 276, pp. 539-556, 2015.

[15] J.M. Guilemany, S. Dosta, J.R. Miguel, "The enhancement of the properties of WC-Co HVOF coatings through the use of nanostructured and microstructured feedstock powders", Surface \& Coatings Technology, Vol. 201, pp.1180, 2006.

[16] Chang-Jiu Li, Guan-Jun Yang, "Relationships between feedstock structure, particle parameter, coating deposition, microstructure and properties for thermally sprayed conventional and nanostructured
WC-Co", International journal of refractory metals and hard materials, Vol. 392, 2013.

[17] Younis, A.A. Alhammali "Microstructure, mechanical properties and sliding wear behavior ofthermally sprayed cermet coatings", $\mathrm{PhD}$ thesis, University of Nottingham, U. K, 2016.

[18] Y. Danlos $\square$, S. Costil, H. Liao, C. Coddet, "Influence of Ti-6Al-4 V and $\mathrm{Al} 2017$ substrate morphology on $\mathrm{Ni}-\mathrm{Al}$ coating adhesion Impacts of laser treatments", Surface \& Coatings Technology, Vol. 205, pp. 2702-2708, 2011

[19] M. Parco, Lidong Zhao, JochenZwick et al, "Investigation of HVOF spraying on magnesium alloys", Surface and Coatings Technology, Vol. 201 3269-3274, 2006.

[20] M. Couto, S. Dosta, J.M. Guilemany, "Comparison of the mechanical and electromechanical properties of WC-17 and 12Co coatings onto A17075-T6 obtained by high velocity oxy-fuel and cold gas spraying", Surface and Coatings Technology, Vol. 268, pp. 180-189, 2015.

[21] M. Magnani, P.H. Suegama, N. Espallargas, S. Dosta et al, "Influence of HVOF parameters on the corrosion and wear resistance of WC-Co coatings sprayed on AA7050 T7", Surface and Coatings Technology, Vol. 202, pp. 4746-4757, 2008.

[22] G.C. Saha, T. I. Khan, G.A. Zhang, "Erosion-corrosion resistance of microcrystalline and near nanocrystalline WC-17Co high velocity oxy-fuel thermal spray coatings", Corrosion Science, Vol. 53, pp. 2106-2114, 2011.

[23] A. K. Basak, J.-p. Celis et al, "Effect of nanostructuring and $\mathrm{Al}$ alloying on corrosion behavior of thermal sprayed WC-Co coatings", Materials Science \& Engineering A, Vol. 558, pp. 377-385, 2012. 